\title{
Diagnosis dan Tatalaksana Emboli Air Ketuban
}

\author{
Dwiana Sulistyanti ${ }^{1}$, Yusmein Uyun ${ }^{2}$ \\ ${ }^{1}$ Bagian SMF Anestesiologi dan Terapi Intensif Fakultas Kedokteran Universitas Mulawarman-RSU AW Syahranie \\ Samarinda, ${ }^{2}$ Bagian SMF Anestesiologi dan Terapi Intensif Fakultas Kedokteran Universitas Gadjah Mada-RSUP \\ Dr. Sardjito Yogyakarta
}

\begin{abstract}
Abstrak
Emboli air ketuban merupakan sindrom katastrofik yang terjadi selama kehamilan dan persalinan atau segera setelah melahirkan. Emboli air ketuban adalah peristiwa masuknya air ketuban yang mengandung sel-sel janin dan material debris lainnya ke dalam sirkulasi maternal yang menyebabkan kolaps kardiorespirasi. Patofisiologinya sampai saat ini belum jelas. Ada tiga faktor utama yang menyebabkan masuknya air ketuban kedalam sirkulasi ibu yaitu robekan amnion dan korion, terbukanya vena ibu baik melalui vena-vena endoserviks, sinus venosus subplasenta atau akibat laserasi segmen bawah rahim serta adanya tekanan yang mendesak masuknya air ketuban kedalam sirkulasi ibu. Gambaran klinisnya sesak yang tiba-tiba, gagal nafas dan hipotensi yang diikuti oleh kolaps kardiovaskuler, DIC dan kematian. Emboli air ketuban mempunyai angka morbiditas dan mortalitas yang tinggi. Pengenalan dini dan diagnosis emboli air ketuban sangat penting untuk meningkatkan angka harapan hidup maternal maupun janin. Penatalaksanaan emboli air ketuban bersifat non spesifik dan suportif, yaitu meningkatkan oksigenasi, memperbaiki sirkulasi, dan memperbaiki koagulopati diikuti dengan prinsip-prinsip basic life support dan advanced life support, dengan fokus utama yaitu stabilisasi kardiopulmonal maternal secara cepat. Tujuan utama yang paling penting adalah mencegah bertambah beratnya hipoksia dan gagal organ yang lebih lanjut. Resusitasi cepat sangat diperlukan tergantung pada keadaan klinis pasien. Pasien dengan emboli air ketuban mempunyai prognosis yang sangat jelek. Sampai saat ini, sindroma ini tidak dapat diprediksikan atau dicegah. Dengan diagnosis awal yang baik, resusitasi cepat dan pendekatan multidisiplin yang baik akan meningkatkan prognosis, memperbaiki mortalitas dan morbiditas maternal maupun fetal.
\end{abstract}

Kata kunci: DIC, emboli air ketuban, kolaps kardiovaskuler, koagulopati

\section{Diagnostic and Management of Amniotic Fluid Embolism}

\begin{abstract}
Amniotic fluid embolism (AFE) is a catastrophic syndrome that occurs during pregnancy and childbirth or immediately after delivery. Amniotic fluid embolism is an event when amniotic fluid containing fetal cells and other debris enter the maternal circulation, which causes cardiorespiratory collapse. The pathophysiology is not yet clear. There are three main factors that cause the entry of amniotic fluid into the mother's circulation, i.e. tearing of the amnion and chorion, an opening of the maternal veins either through the endocervical veins, subplacental venous sinuses or due to laceration of the lower uterine segment and the pressure that forces the entry of amniotic water into the mother's circulation. The clinical features are sudden onset of breathlessness, respiratory failure and hypotension followed by cardiovascular collapse, DIC and death. Amniotic fluid embolism has high morbidity and mortality rates. Early recognition and diagnosis of amniotic embolism are very important to increase the life expectancy of both the maternal and the fetus. Management of amniotic fluid embolism is non-specific and supportive, namely increasing oxygenation, improving circulation, and improving coagulopathy followed by the principles of basic life support and advanced life support, with the main focus of rapid maternal cardiopulmonary stabilization. The main and most important goal is to prevent further progression of hypoxia and organ failure. Rapid resuscitation is necessary, depending on the clinical condition of the patient. Patients with amniotic fluid embolism have a very poor prognosis. Until recently, this syndrome could not be predicted or prevented. With a good initial diagnosis, rapid resuscitation and a good multidisciplinary approach will improve prognosis, improve maternal and fetal mortality and morbidity.
\end{abstract}

Key words: amniotic fluid embolism, cardiovascular collapse, coagulopathy, DIC 


\section{Pendahuluan}

Emboli air ketuban merupakan kejadian yang jarang terjadi dan merupakan suatu sindrom katastrofik yang terjadi selama kehamilan dan persalinan atau segera setelah melahirkan (post partum). Emboli air ketuban juga merupakan penyebab penting kematian maternal dan kematian janin terutama di negara-negara berkembang. Emboli air ketuban memiliki angka morbiditas dan mortalitas yang tinggi. Mortalitas dan morbiditas emboli air ketuban telah menurun secara dramatis akhir-akhir ini, dimana dilaporkan mortalitas maternal adalah sekitar $16 \%$. Insidensi yang sebenarnya tidak jelas, hal ini disebabkan sindrom ini sulit untuk dikenali dan didiagnosis. ${ }^{1}$

Emboli air ketuban adalah peristiwa masuknya air ketuban yang mengandung sel-sel janin dan material debris lainnya ke dalam sirkulasi maternal yang menyebabkan kolaps kardiorespirasi. Emboli air ketuban merupakan suatu kasus komplikasi obstetri yang tidak dapat diprediksikan dan dicegah, ditandai dengan hipoksia peripartum akut, kolaps hemodinamik dan koagulopati. Kelainan ini pertama kali diajukan oleh Ricardo Meyer pada tahun 1926 dan diterangkan lebih jelas oleh Steiner dan Lushbaugh pada tahun 1941, setelah mereka menemukan debris janin pada sirkulasi pulmonal wanita yang meninggal selama persalinan. ${ }^{2}$

Emboli air ketuban dapat terjadi jika air ketuban masuk melalui pembuluh darah yang terbuka kedalam sirkulasi maternal, seperti pada keadaan plasenta akreta, setelah tindakan bedah sesar, ruptur uteri atau melalui robekan vena-vena didaerah endoserviks. Data terbaru dari National Registry menunjukan bahwa proses tersebut lebih menyerupai reaksi anafilaksis/reaksi imun daripada emboli, dan penggunaan istilah anaphylactoid syndrome of pregnancy lebih disarankan karena sel-sel janin atau komponen air ketuban tidak ditemukan pada semua wanita yang menunjukkan tanda dan gejala yang berhubungan dengan emboli air ketuban. ${ }^{2,3}$

Sebagian besar kasus emboli air ketuban terjadi selama persalinan $(80 \%)$, namun dapat pula terjadi sebelum persalinan $(20 \%)$ atau setelah kelahiran bayi. Sekitar $25 \%$ pasien akan meninggal dalam onset 1 jam. Manifestasi klinik emboli air ketuban yang klasik adalah dyspnea, kegagalan respiratorik dan hipotensi yang diikuti dengan kolaps kardiovaskuler, disseminated intravascular coagulation (DIC) dan kematian. Patofisiologi dari emboli air ketuban sampai saat ini masih belum jelas. Penatalaksanaan emboli air ketuban masih tetap berupa terapi suportif bukan kausatif, dan terfokus pada stabilisasi sistem kardiopulmonal secara cepat. Tujuan terpenting dari terapi emboli air ketuban adalah untuk mencegah terjadinya hipoksia tambahan dan kegagalan organ.

Prognosis dan mortalitas emboli air ketuban telah membaik secara signifikan dengan diagnosis awal dan penanganan resusitasi secara cepat dan tepat, disamping kemajuan teknologi dalam critical care life support. Walaupun demikian, sekitar $61 \%$ pasien yang selamat, sebagian besar memiliki kerusakan neurologis permanen akibat hipoksia (permanent hypoxia-induced neurological damage). Mortalitas fetal sekitar 21\% dan 50\% dari yang berhasil selamat mengalami kerusakan neurologis yang permanen. ${ }^{3,4}$ Maka dari itu tujuan dari referat ini adalah untuk memberi gambaran mengenai emboli air ketuban yang bisa terjadi pada kehamilan dan langkah-langkah apa yang bisa kita lakukan sehingga dapat mengurangi angka kematian ibu maupun kematian janin.

\section{Insiden}

Insidensi dari emboli air ketuban tidak diketahui secara pasti karena tidak akuratnya laporan mortalitas maternal, terbatasnya data tentang kasus-kasus yang tidak fatal dan kenyataan bahwa emboli air ketuban sulit diidentifikasi. Tetapi tetap dilaporkan bahwa angka kejadian emboli air ketuban sekitar 1:8000-1:80.000 kehamilan. Insidensi emboli air ketuban dilaporkan lebih tinggi pada pasien yang menjalani operasi sesar (22/100.000 kelahiran) dibandingkan pada pasien yang melahirkan pervaginam $(8 / 100.000$ kelahiran). Insidensi juga meningkat lebih tinggi secara signifikan pada wanita umur 30-39 tahun (17/100.000) dibandingkan wanita umur 15-29 
tahun (8/100.000). ${ }^{4}$ Dilaporkan juga bahwa emboli air ketuban dapat terjadi pada awal gestasi, aborsi trimester kedua, selama amniosintesis atau pada trauma tumpul abdominal. ${ }^{3}$

\section{Cairan Ketuban}

Cairan ketuban adalah cairan jernih yang normal terdapat dalam rongga amniotik. Volume rata-rata sekitar $1000 \mathrm{ml}$ ditemukan saat kehamilan aterm, meskipun hal ini mungkin bervariasi dari beberapa milimeter sampai banyak liter dalam kondisi abnormal. Cairan ketuban diproduksi oleh janin maupun ibu, dan keduanya memiliki peran tersendiri pada setiap usia kehamilan. Pada kehamilan awal, cairan ketuban sebagian besar diproduksi oleh sekresi epitel selaput amnion. Dengan bertambahnya usia kehamilan, produksi cairan ketuban didominasi oleh kulit janin dengan cara difusi membran. Pada kehamilan 20 minggu, saat kulit janin mulai kehilangan permeabilitas, ginjal janin mengambil alih peran tersebut dalam memproduksi cairan ketuban.

Pada kehamilan aterm, sekitar $500 \mathrm{ml}$ per hari cairan ketuban disekresikan dari urin janin dan $200 \mathrm{ml}$ berasal dari cairan trakea. Pada penelitian dengan menggunakan radioisotop, terjadi pertukaran sekitar $500 \mathrm{ml}$ per jam antara plasma ibu dan cairan amnion. ${ }^{5}$ Pada awal kehamilan, cairan ketuban adalah suatu ultrafiltrat plasma ibu. Pada awal trimester kedua, cairan ini terdiri dari cairan ekstrasel yang berdifusi melalui kulit janin sehingga mencerminkan komposisi plasma janin. Namun setelah 20 minggu, kornifikasi kulit janin menghambat difusi ini dan cairan amnion terutama terdiri dari urin janin. Urin janin mengandung lebih banyak urea, kreatinin dan asam urat dibandingkan plasma. Selain itu juga mengandung sel janin yang mengalami deskuamasi, verniks, lanugo dan berbagai sekresi. Karena zat-zat ini bersifat hipotonik, maka seiring bertambahnya usia gestasi, osmolalitas cairan ketuban berkurang. Cairan paru memberi kontribusi kecil terhadap volume amnion secara keseluruhan dan cairan yang tersaring melalui placenta berperan membentuk sisanya. $98 \%$ cairan ketuban adalah air dan sisanya adalah elektrolit, protein, peptid, karbohidrat, lipid dan hormon. Terdapat sekitar 38 komponen biokimia dalam cairan ketuban, diantaranya adalah protein total, albumin, globulin, alkalin aminotransferase, aspartat aminotransferase, alkalin fosfatase, $\gamma$-transpeptidase, kolinesterase, kreatinin kinase, isoenzim keratin kinase, dehidrogenase laktat, dehidrogenase hidroksibutirat, amilase, glukosa, kolesterol, trigliserida, High Density Lipoprotein (HDL), low-density lipoprotein (LDL), very-low density lipoprotein (VLDL), apoprotein A1 dan B, lipoprotein, bilirubin total, bilirubin direk, bilirubin indirek, sodium, potassium, klorid, kalsium, fosfat, magnesium, bikarbonat, urea, kreatinin, anion gap, urea dan osmolalitas. ${ }^{5-7}$

Faktor pertumbuhan epidermis (epidermal growth factor, EGF) dan faktor pertumbuhan mirip EGF, misalnya transforming growth factor- $\alpha$, terdapat di cairan ketuban. Ingesti cairan ketuban ke dalam paru dan saluran cerna mungkin meningkatkan pertumbuhan dan diferensiasi jaringan-jaringan ini melalui gerakan inspirasi dan menelan cairan ketuban. ${ }^{6,8}$ Beberapa penanda (tumor marker) juga terdapat di cairan ketuban termasuk $\alpha$-fetoprotein (AFP), antigen karsinoembrionik (CEA), feritin, antigen kanker 125 (CA-125) dan 199 (CA-199). ${ }^{6,8}$

\section{Patofisiologi Emboli Air Ketuban}

Emboli merupakan segala sesuatu yang masuk ke sirkulasi yang dapat menyebabkan sumbatan pada aliran darah di organ tertentu. Oksigen yang dibawa oleh darah dipompa keseluruh tubuh melalui arteri dimana arteri mempunyai cabang-cabang yang akhirnya semakin kecil secara bertahap. Jika embolus melewati arteri maka dia akan mencapai bagian yang terdalam/ terkecil sehingga menyumbat aliran darah pada organ tempat embolus berada dan menyebabkan organ tersebut akhirnya menjadi nekrosis akibat kekurangan oksigen. Dalam kehamilan terdapat 3 jenis emboli yang bisa terjadi yaitu tromboemboli paru, emboli air ketuban dan emboli udara vena. Presentasi tiap-tiap emboli ini memiliki insidensi dan perjalanan klinis yang bervariasi. 
Sebagai contoh, emboli udara vena sering terjadi selama operasi sesar. Gejala-gejalanya bersifat transien, dan diagnosis sering kali tidak terdeksi. Sebaliknya, emboli air ketuban jarang terjadi, namun presentasi klinisnya bersifat berbahaya. ${ }^{9}$ Pada pasien obstetrik, banyak kejadian emboli terjadi pada intrapartum atau postpartum. Anestesi paling sering terlibat dalam melakukan resusitasi pasien. Pengenalan, diagnosis dan penatalaksaan dini diperlukan untuk mengurangi morbiditas dan mortalitas akibat emboli air ketuban ini.

Cairan ketuban dan selaput ketuban merupakan mekanisme perlindungan yang penting untuk perkembangan janin. Selama kehamilan selaput ketuban memisahkan cairan ketuban dengan sirkulasi maternal. Pada proses persalinan, pembuluh darah uterus di permukaan endometrium menjadi terpapar langsung dengan cairan ketuban. Biasanya kontraksi uterus sangat efektif untuk membuat pembuluh darah sangat mengecil. Oleh karena itu pada saat ketuban pecah, untuk terjadinya emboli air ketuban harus ada tekanan yang menyebabkan cairan ketuban masuk kedalam sirkulasi maternal. Tempat implantasi plasenta merupakan salah satu tempat yang berpotensi masuknya cairan ketuban ke dalam sirkulasi, terutama ketika terjadi pelepasan plasenta. Hal ini biasanya tidak terjadi jika kontraksi uterus baik. Di sisi lain, luka kecil pada segmen bawah rahim dan endoserviks selama kehamilan dan persalinan sekarang dianggap sebagai salah satu tempat masuknya emboli. Gejala yang ditimbulkan tergantung dari besarnya sumbatan pada arteri pulmonalis. ${ }^{3,4}$ Satu penelitian, melaporkan pada kasus kematian karena emboli air ketuban, pada pemeriksaan postmortem mengungkapkan adanya penyumbatan oleh emboli air ketuban di pembuluh darah servikal dan paru. Ada tiga faktor utama yang menyebabkan masuknya air ketuban kedalam sirkulasi ibu adalah robekan amnion dan korion, terbukanya vena ibu baik melalui venavena endoserviks, sinus venosus subplasenta atau akibat laserasi segmen bawah rahim, dan tekanan yang mendesak masuknya air ketuban kedalam sirkulasi ibu. $^{4}$

Patofisiologi emboli air ketuban sampai saat ini dianggap masih belum jelas. Pada masa lalu, diperkirakan kejadian emboli air ketuban itu disebabkan oleh karena masuknya jaringan janin atau cairan ketuban kedalam sirkulasi maternal yang kemudian menyebabkan vasospasme pulmonal, gagal jantung, hipoksemia dan kematian. Emboli air ketuban sebenarnya merupakan reaksi sistem imun terhadap antigen janin yang terdapat dalam cairan ketuban, bukan hanya sekedar proses emboli. Emboli air ketuban disebabkan karena antigen janin dalam cairan ketuban merangsang pelepasan mediatormediator imun endogen sehingga menyebabkan reaksi anafilaksis. Cairan ketuban mengandung komponen yang bervariasi dan komponenkomponen ini yang berperan dalam patofisiologi emboli air ketuban melalui mekanisme yang berbeda-beda. Untuk mediator biokimia dalam bentuk larutan menyebabkan gambaran reaksi anafilaksis dengan banyak sistem yang terlibat, sedangkan mediator biokimia dalam bentuk suspensi bertanggung jawab hanya efek minor yang menyebabkan obstruksi mekanik yang nyata. Hipoksia peripartum akut, kolaps hemodinamik dan koagulopati seharusnya digambarkan sebagai sindroma anafilaksis kehamilan, dan bukan emboli air ketuban. ${ }^{3}$ Respon terhadap emboli air ketuban itu ada 2 fase, yaitu: ${ }^{3}$

Fase 1: cairan ketuban dan sel-sel janin masuk ke dalam sirkulasi maternal menyebabkan dilepasnya mediator-mediator biokimia yang mengakibatkan vasospasme arteri pulmonal yang diikuti dengan hipertensi pulmonal. Hal ini menyebabkan tekanan di ventrikel kanan meningkat dan terjadi disfungsi ventrikel kanan, kemudian akan menyebabkan hipoksemia dan hipotensi, selanjutnya akan mengakibatkan kerusakan otot jantung dan pembuluh darah paru. Fase 2: timbul pada pasien yang mampu bertahan dari fase awal. Di fase ini akan timbul gagal jantung kiri dan udem paru. Mediator-mediator biokimia juga akan merangsang terjadinya DIC yang akan menyebabkan perdarahan masif dan atonia uteri.

Sedangkan penelitian lain menyebutkan bahwa, patofisiologi emboli air ketuban terdiri dari 3 mekanisme yaitu: ${ }^{4}$

Mekanisme sumbatan pembuluh darah: gejala 
Tabel 1. Komponen Cairan Ketuban

\begin{tabular}{ll}
\hline Larutan (mediator biokimia) & Suspensi \\
Surfaktan & Rambut lanugo \\
Endotelin & Vernik kaseosa \\
Leukotrien C4 \& D4 & $\begin{array}{l}\text { Squamous fetal } \\
\text { IL-1 \& TNF- } \alpha\end{array}$ \\
$\begin{array}{l}\text { Bile-stained } \\
\text { meconium }\end{array}$ \\
Tromboksan A2 & Fetal gut mucin \\
Asam arakhidonat & Trofoblas \\
Tromboplastin & \\
Kolagen \& tissue factor II & \\
Phospolipase A2 & \\
\hline
\end{tabular}

klinis timbul akibat air ketuban masuk kedalam sirkulasi maternal melalui pembuluh darah pada endoserviks dan segmen bawah rahim selama proses persalinan, sehingga menyebabkan sumbatan dalam aliran darah termasuk sumbatan pada aliran darah paru, kemudian akan menyebabkan hipertensi pulmonal, gagal jantung, hipotensi dan kematian.

Mekanisme akibat efek inflamasi pada sistem sirkulasi maternal: masuknya air ketuban dan sel-sel janin menyebabkan terlepasnya mediatormediator biokimia, dan mediator-mediator ini akan memicu respon sistem inflamasi, sehingga secara klinis memberikan gambaran seperti syok anafilaksis dan syok sepsis. Cairan ketuban mempunyai efek vasoaktif dan prokoagulasi yang disebabkan karena adanya prostaglandin, endotelin, faktor aktifasi platelet, leukotrien, bradikinin dan tissue factor. Sehingga gambaran klinis emboli air ketuban meliputi koagulopati, peningkatan permeabilitas kapiler, vasokonstriksi pembuluh darah paru, jantung dan sistemik, serta bronkospasme yang semuanya didukung oleh mekanisme humoral.

Mekanisme imunologi: yang berperan serta pada mekanisme ini adalah sistem komplemen, tetapi patofisiologisnya masih belum jelas.

Beberapa mekanisme diatas, menjadi dasar patofisiologi terjadinya emboli air ketuban. Dengan patofisiologi ini kita bisa melihat beberapa perubahan yang terjadi pada sistem hemodinamik, sistem pulmonal dan sistem koagulasi. ${ }^{3,4,10}$

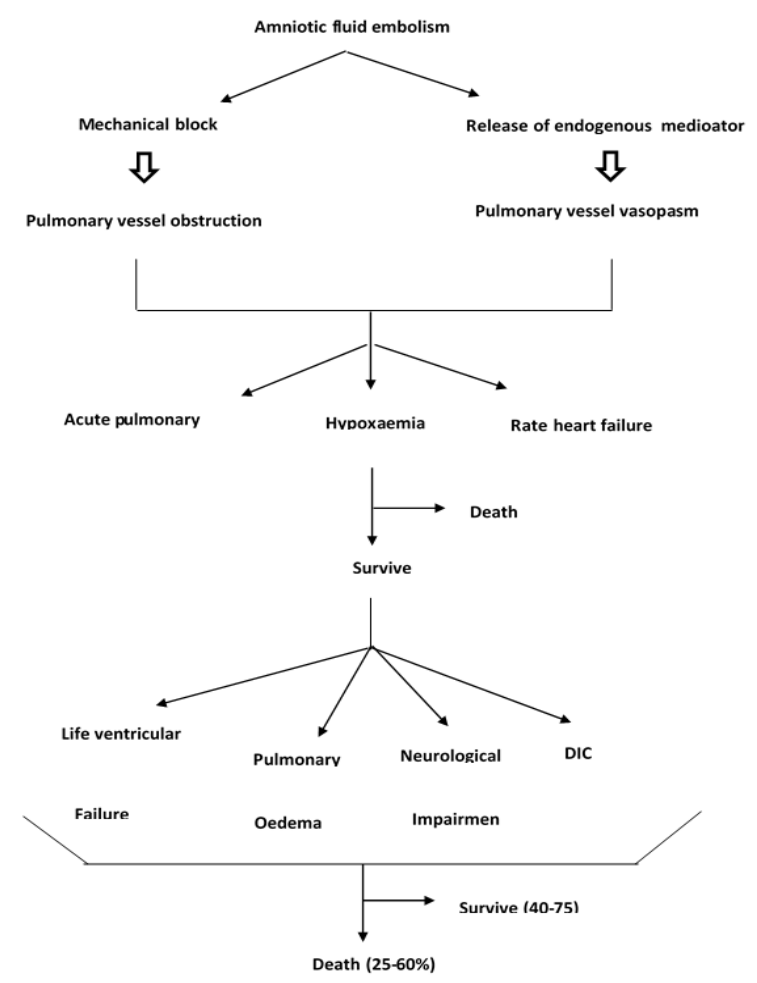

Gambar 1. Mekanisme Patofisiologi Emboli Air Ketuban ${ }^{3}$

\section{Hemodinamik}

Cairan ketuban dan sel-sel janin menyebabkan peningkatan tahanan sistemik dan pulmonal sehingga terjadi hipertensi pulmonal akut. Pasien yang mampu bertahan pada tahap ini akan mengalami gagal jantung kiri dan udem paru. Penyebab disfungsi otot jantung masih belum jelas. Mungkin disebabkan karena hipoksia akut atau karena depresi langsung otot jantung akibat komponen yang terdapat dalam cairan ketuban. Adanya endotelin (vasokonstriktor poten) dan faktor-faktor humoral seperti histamin, prostaglandin, serotonin, tromboksan, dan leukotrien dapat menyebabkan depresi jantung, penurunan cardiac output, hipertensi pulmonal dan DIC. Mekanisme terjadinya hampir sama dengan mekanisme syok anafilaksis dan syok sepsis.

Pulmonal

Vasospasme pulmonal dan disfungsi ventrikel menyebabkan hipoksemia akut dan berat, yang nantinya akan menyebabkan gangguan neurologis yang permanen. Pada pasien yang mampu bertahan, primary lung injury sering 


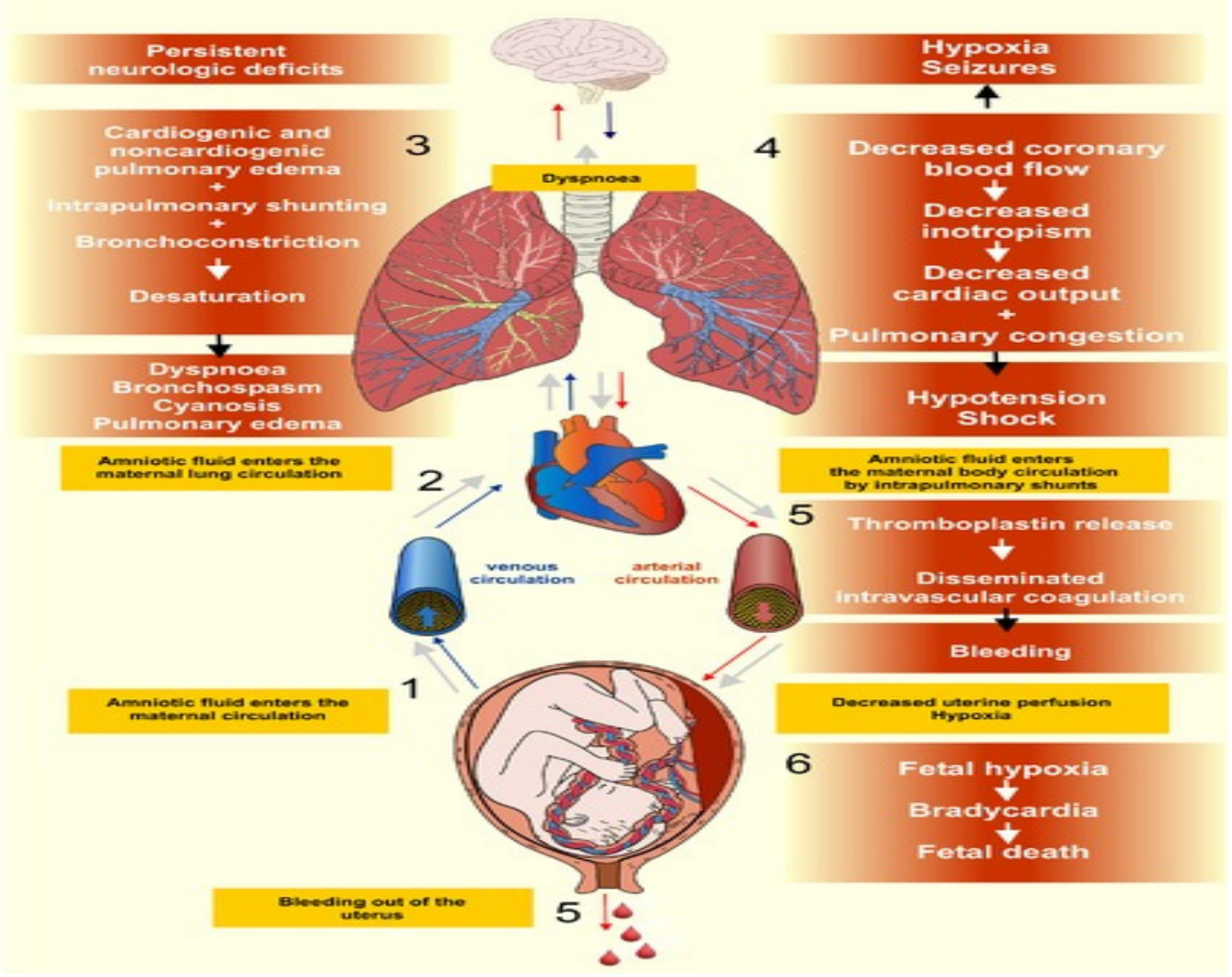

Gambar 2. Patofisiologi Emboli Air Ketuban ${ }^{12}$

berkembang menjadi acute respiratory distress syndrome (ARDS).

\section{Koagulasi}

$83 \%$ pasien yang mampu betahan akan mengalami DIC dengan ataupun tanpa perdarahan yang signifikan. Cairan ketuban mengandung faktor koagulasi II, VII dan X. Aktifasi faktor X akan menyebabkan agregasi platelet, melepaskan platelet faktor III dan mempunyai efek seperti tromboplastin. Satu penelitian mengatakan bahwa cairan ketuban mengandung faktor jaringan, yang berfungsi sebagai prokoagulasi. Sumber prokoagulasi adalah kulit janin yang terkelupas dan sel-sel epitel dari sistem pernafasan, gastrointestinal dan genitourinaria janin. Faktor jaringan bertanggung jawab terhadap aktifasi jalur ekstrinsik pengikatan faktor VII. Faktor ini yang dianggap memicu pembekuan dengan mengaktifasi faktor $\mathrm{X} .{ }^{10}$ Sebagian beranggapan ketika terbentuk pembekuan di pembuluh darah akan mengakibatkan pembentukan trombin lokal dan menyebabkan vasokonstriksi dan trombosis mikrovaskuler dan pelepasan endotelin vaskuler. Endotelin akan menekan kontraksi miometrium dan otot jantung sehingga mengakibatkan perdarahan masif (karena atonia uteri) dan kolaps hemodinamik. Beberapa keadaan yang dianggap memiliki resiko tinggi untuk terjadinya emboli air ketuban adalah usia hamil yang tua ( $>35$ tahun), multiparitas,

\section{Tabel 2. Tanda dan Gejala Klinis Emboli Air} Ketuban $^{4}$

\begin{tabular}{|c|c|}
\hline Sistem organ & Tanda dan gejala \\
\hline $\begin{array}{l}\text { Umum Pernafasan } \\
\text { Kardiovaskular }\end{array}$ & $\begin{array}{l}\text { rasa tertusuk, kesemutan, } \\
\text { pusing, nyeri dada, muntah, } \\
\text { batuk sesak, bronko- } \\
\text { spasme, udem paru, ARDS, } \\
\text { hipotensi, transient hy- } \\
\text { pertension, sianosis, nyeri } \\
\text { dada, henti jantung }\end{array}$ \\
\hline Hematologi & $\begin{array}{l}\text { kejang, sakit kepala, hilang } \\
\text { kesadaran koagulopati, } \\
\text { DIC, bradikardi janin }\end{array}$ \\
\hline
\end{tabular}


Tabel 3. Diagnosis Banding Emboli Air Ketuban ${ }^{1,13}$

\begin{tabular}{l}
\hline Sebab obstetri \\
\hline Perdarahan akut \\
Solusio placenta \\
Ruptur uteri \\
Atonia uteri \\
Eklamsi \\
Kardiomiopati peripartum \\
\hline Sebab Anestesi \\
\hline High spinal anesthesia \\
Aspirasi \\
Toksisitas lokal anestesi \\
\hline Sebab non obstetri \\
\hline Emboli paru \\
Emboli udara \\
Anafilaksis \\
Sepsis/syok sepsis \\
\hline
\end{tabular}

adanya mukoneum, laserasi serviks, kematian janin dalam kandungan, pengeluaran bayi yang terlalu cepat, placenta akreta, polihidramnion, ruptur uteri, khorioamnionitis, amniosintesis, operasi sesar, eklamsi, gawat janin, makrosomia, induksi persalinan, kehamilan ganda, placenta previa, solutio placenta, alat-alat persalinan pervaginam dan trauma abdomen. ${ }^{1,4,11}$

\section{Diagnosis Emboli Air Ketuban}

Pengenalan dini dan diagnosis emboli air ketuban sangat penting untuk meningkatkan angka harapan hidup maternal maupun janin. Akhir-akhir ini diagnosis emboli air ketuban dibuat berdasarkan hasil otopsi, dimana ditemukan adanya selsel janin atau komponen cairan ketuban pada pembuluh darah paru maternal. Diagnosis emboli air ketuban tidak dibuat hanya berdasarkan gejala klinis dan laboratorium saja, karena tidak ada pemeriksaan laboratorium yang spesifik untuk mengkonfirmasi emboli air ketuban, tetapi beberapa pemeriksaan laboratorium dapat mendukung diagnosis. ${ }^{1,3,4,10,13}$

Kriteria diagnostik emboli air ketuban meliputi: 1,10 hipotensi akut atau henti jantung, hipoksia akut, ditandai dengan dispnea, sianosis atau henti nafas, koagulopati, ditandai dengan hasil pemeriksaan laboratorium yang menunjukkan penggunaan intravaskuler atau fibrinolisis atau perdarahan yang berat tanpa ada sebab yang jelas, timbulnya tanda dan gejala seperti tersebut diatas terjadi

Tabel 4. Diagnosis Emboli Air Ketuban ${ }^{3}$

\begin{tabular}{ll}
\hline Pemeriksaan & Hasil \\
\hline Tes non spesifik & \\
Full blood counts & hemoglobin rendah \\
Koagulasi & $\begin{array}{l}\text { trombositopeni, PT dan APTT meningkat, } \\
\text { fibrinogen rendah } \\
\text { hipoksemia, PaCO2 meningkat }\end{array}$ \\
Arterial blood gas & normal, kardiomegali, udem paru \\
Foto thorak & right heart strain, aritmia \\
EKG & V/Q mismatch \\
V/Q scans & disfungsi ventrikel kanan atau kiri, EF rendah \\
Ekokardiografi & \\
Tes lebih spesifik & sel squamous dengan neutrofil dan debris \\
Contoh arteri pulmonal & janin \\
Sialyl Tn antigen & meningkat \\
& meningkat \\
serum tryptase level & normal atau meningkat \\
\hline
\end{tabular}

PT: prothrombine time; APTT: activated partial thromboplastin time; V/Q: ventilation/perfusion 
selama persalinan, operasi sesar atau dilatasi dan evakuasi atau dalam 30 menit postpartum, tidak ada kelainan lain yang bisa menjelaskan timbulnya gejala-gejala dan tanda yang didapat.

Tanda dan gejala klinis yang sering ditemui pada emboli air ketuban adalah hipotensi, gawat janin, udem paru atau ARDS, henti jantung, sianosis, koagulopati, sesak nafas, kejang, atonia uteri, bronkospasme, transient hypertension, batuk, sakit kepala dan nyeri dada. ${ }^{1,3,4,10,13}$ Pemeriksaan penunjang lain yang mendukung untuk diagnosis emboli air ketuban bisa dilihat pada tabel 4 dibawah ini. $^{3}$

\section{Tatalaksana}

Faktor yang menentukan dalam penatalaksanaan emboli air ketuban adalah pengenalan dini emboli air ketuban, resusitasi cepat dan mengeluarkan janin. Pengenalan dini emboli air ketuban penting untuk meningkatkan angka harapan hidup maternal maupun janin. Penatalaksanaan emboli air ketuban bersifat non spesifik dan suportif (tabel 5), diikuti dengan prinsip-prinsip basic life support dan advanced life support, dengan fokus utama yaitu stabilisasi kardiopulmonal maternal secara cepat. ${ }^{1}$ Pada umumnya pasien membutuhkan perawatan di ruang intensif (ICU) setelah dilakukan stabilisasi. Tujuan utama yang paling penting adalah mencegah bertambah beratnya hipoksia dan gagal organ yang lebih lanjut. Resusitasi cepat sangat diperlukan tergantung pada keadaan klinis pasien. Penatalaksanaan emboli air ketuban yaitu meningkatkan oksigenasi, memperbaiki sirkulasi, dan memperbaiki koagulopati. Jika keadaan klinis memungkinkan, bisa dipasang arterial line dan kateter arteri pulmonal untuk memandu dalam pemberian terapi. Jika henti jantung terjadi sebelum persalinan sedangkan resusitasi tidak segera berhasil janin sebaiknya segera dilahirkan dalam beberapa menit dengan operasi sesar perimortem. ${ }^{1}$

Oksigen $100 \%$ diberikan untuk mempertahankan saturasi oksigen yang normal, dan pemasangan pulse oxymetri bermanfaat untuk mengawasi saturasi oksigen pada pasien yang kritis. Semua pasien yang sadar diberikan oksigen dengan sungkup muka. Intubasi trakea dan ventilasi mekanik dengan oksigen $100 \%$ diberikan pada pasien dengan hipoksemia berat, kejang dan pasien koma. Bantuan hemodinamik perlu diberikan untuk mengatasi hipotensi dan syok. Penggantian volume darah yang hilang dengan cairan kristaloid atau darah mutlak diperlukan. Untuk meningkatkan cardiac output dan mempertahankan tekanan darah, obatobat vasopresor seperti dopamin, dobutamin, milrinon, epinefrin, norepinefrin dan efedrin dapat diberikan. Untuk pasien dengan hipertensi pulmonal berat dapat diberikan nitric oxide, sebagai selektif vasodilator pulmonal, prostasiklin dan sildenafil. ${ }^{13-15}$ Udem paru sangat sering terjadi dan harus mendapat perhatian terhadap status keseimbangan cairan.

Kortikosteroid membantu dalam penanganan emboli air ketuban, karena terdapat proses imun pada keadaan ini. Hidrokortison diberikan dengan dosis $500 \mathrm{mg}$ secara intra vena setiap 6 jam, sampai terjadi respon. Pemberian furosemid akan memperbaiki diuresis. ${ }^{1}$ Dalam waktu kurang dari 4 jam, pasien yang mampu bertahan akan mengalami perdarahan masif karena DIC. Jika terjadi koagulopati, perlu diberikan komponen darah sesuai dengan hasil pemeriksaan laboratorium. Jika angka trombosit kurang dari 20.000/mm3, harus diberikan transfusi trombosit. Prothrombine time (PT) biasanya memanjang karena faktor-faktor pembekuan telah banyak dipakai. Jika nilai PT memanjang 1,5 kali dari nilai normal, disarankan mulai pemberian fresh frozen plasma (FFP) untuk memperbaiki nilai PT. Activated partial thromboplastin time (aPTT) mungkin dalam batas normal atau memendek. Jika kadar fibrinogen kurang dari $100 \mathrm{mg} / \mathrm{dl}$, perlu diberikan cryoprecipitate. Setiap unit cryoprecipitate meningkatkan kadar fibrinogen sebanyak $10 \mathrm{mg} / \mathrm{dl} .^{1,13,14}$

Sebagaimana dijelaskan diatas, pasien dalam kondisi kritis yang beresiko terhadap hipoksemia, monitor saturasi oksigen dapat bermanfaat. Pengamatan denyut jantung janin harus dikerjakan bila janin belum dilahirkan dan viable. Selama fase awal dari kolaps hemodinamik dan hipoksemia, biasanya terjadi bradikardi janin yang nyata. Respon perbaikan denyut jantung 
Tabel 5. Terapi suportif pada Emboli Air Ketuban

Terapi hipoksia dengan oksigen 100\%

Terapi hipotensi dengan resusitasi cairan isotonis dan vasopresor

Terapi memperbaiki kontraktilitas ventrikel kiri dengan cairan dan inotropik

Terapi DIC dan koagulopati dengan FFP, cryoprecipitate, fibrinogen dan factor replacement

Terapi perdarahan dengan tranfusi PRC dan trombositopeni dengan trombosit

DIC: Disseminated intravascular coagulation; FFP: Fresh frozen plasma; PRC: Packed red cell

janin terhadap penanganan pada ibu dapat dipantau dengan pengamatan denyut jantung janin. Beberapa terapi juga dilaporkan digunakan untuk terapi emboli air ketuban anatara lain operasi bypass jantung paru, oksigenasi membran ekstrakorporeal, dan hemofiltrasi atau transfusi tukar (tabel 6). ${ }^{15}$

\section{Prognosis}

Pasien dengan emboli air ketuban mempunyai prognosis yang sangat jelek. Sampai saat ini, sindromainitidakdapatdiprediksikanataudicegah. Dengan diagnosis awal yang baik, resusitasi cepat dan pendekatan multidisiplin yang baik akan meningkatkan prognosis, memperbaiki mortalitas dan morbiditas maternal maupun fetal. ${ }^{1,4,13}$

\section{Simpulan}

Emboli air ketuban merupakan sindrom katastrofik yang terjadi selama kehamilan dan persalinan atau segera setelah melahirkan. Emboli air ketuban mempunyai angka morbiditas dan mortalitas yang tinggi. Patofisiologinya sampai saat ini belum jelas. Gambaran klinisnya sesak yang tiba-tiba, gagal nafas dan hipotensi yang diikuti oleh kolaps kardiovaskuler, DIC dan kematian. Penanganannya bersifat suportif dan fokus pada stabilisasi kardiopulmonal ibu. Tujuan terpenting dari terapi emboli air ketuban adalah untuk mencegah terjadinya hipoksia tambahan dan kegagalan organ. Pasien dengan emboli air ketuban mempunyai prognosis yang sangat jelek. Sampai saat ini, sindroma ini
Tabel 6. Terapi terbaru untuk penanganan emboli air ketuban. ${ }^{15}$

\begin{tabular}{l}
\hline Intra-aotic balloon counterpulsation \\
\hline Extracorporeal membrane oxygenation \\
\hline Cardiopulmonary bypass \\
\hline Plasma exchange transfusions \\
\hline Uterine artery embolization \\
\hline Continuous hemofiltration \\
\hline Cell-salvage combined with blood filtration \\
\hline Serum protease inhibitors \\
\hline Inhaled nitric oxide \\
\hline Inhaled prostacyclin \\
\hline Aplication sildenafil \\
\hline High-dose corticossteroids
\end{tabular}

tidak dapat diprediksikan atau dicegah. Dengan diagnosis awal yang baik, resusitasi cepat dan pendekatan multidisiplin yang baik akan meningkatkan prognosis, memperbaiki mortalitas dan morbiditas maternal maupun fetal.

\section{Daftar Pustaka}

1. Toy H. Amniotic fluid embolism. European Journal of General Medicine, 2009;6(2):10815.

2. Tsunemi T, Oi H, Sado T, Naruse K, Noguchi T, Kobayashi H. An Overview of Amniotic fluid embolism: past, present and future directions. The Open Women's Health Journal, 2012;6:24-9.

3. Dedhia JD, Mushambi MC. Amniotic fluid embolism. Continuing Education in Anesthesia, Critical Care \& Pain, 2007;7(5):152-56.

4. Thongrong C, Kasemsiri P, Stawicki SPA. Amniotic fluid embolism. International Journal of Critical Illness and Injury Science, 2013;3(1):51-7.

5. Laughlin D, Knuppel RA. Maternalplacental-fetal unit;fetal \& early neonatal physiology. In: DeCherney AH, Nathan L. 
Current obstetric \& gynecologic diagnosis \& treatment. 9th ed. New York: The McGrawHill Companies;2003.

6. Owen P. Fetal assessment in the third trimester: fetal growth and biophysical methods. In: Chamberlain G, Steer P, editors. Turnbull's obstetrics. 3th ed. London: Churchill Livingstone;2002;147-9; 41-3.

7. Tong XL, Wang L, Gao TB, Qin YG, Xu YP. Potential function of amniotic fluid in fetal development-Novel insight by comparing the composition of human amniotic fluid with umbilical cord and maternal serum at mid and late gestation. Journal Chinna Medical Association,2009 Jul;72(7):368-73.

8. Cunningham FG, Gant NF, Leveno KJ, Gilstrap LC, Hauth JC, Wenstorm KD. William obstetric. 22nd ed. New York. McGraw-Hill Companies, Inc;2005.

9. David H. Embolism. In: Chestnut D. Obstetric Anesthesia Principles and Practice. 3th edition. Philadelphia: Elsevier Mosby; 2004:683-92.
10. Uszynnski M, Uszynnski W. A new approach to the pathomechanism of amniotic fluid embolism: unknown role of amniotic cells in the induction of disseminated intravascular coagulation. Asian Pasific Journal of Reproduction, 2012;1(4):326-9.

11. Dobbenga YA. Responding to amniotic fluid embolis. Association of periOperative Registered Nurses Journal, 2009; 89 (6):1079-88.

12. Hic et nunc. Amniotic fluid embolism. Wikimedia project. 2011 [cited 2011 july 17]; Available from hhtp://www.wikimedia.org/ wiki/ file: amniotic_fluid_embolism.

13. Gist RS, Stafford IP, Leibowitz AB, Beilin Y. Amniotic fluid embolism. Anesth Analg. 2009;108:1599-602.

14. Perozzi KJ, Englert NC. Amniotic fluid embolism an obstetric emergency. Critical Care Nurse journal, 2004;24(4):54-61.

15. Moore J, Baldisseri MR. Amniotic fluid embolism. Critical Care Medicine 2005;33(10 Suppl):279-85. 